\title{
Managing Popular Culture: Comparing Old Order, New Order, and Reform Periods
}

\author{
Hariyadi*) and Dalhar Shodiq \\ Department of Sociology, Faculty of Social and Political Sciences, \\ Jenderal Soedirman University, \\ hariyadi_sosiologi@unsoed.ac.id
}

\begin{abstract}
In the paper, I review the existing literature about the burgeoning of popular culture in Indonesia and how political elites manage popular culture. The review encompasses three major periods in the Indonesian history: Old Order (1945-1967), New Order (1966-1998) and Reform (1998-now). I observe how government in each historical period treated popular culture, and how extensive types of popular culture were developed under different cultural policies. The Old Order government imposed heavy restrictions upon Western popular culture. Meanwhile in the New Order period, the government, with industrialisation programmes and liberalisation policy, paved the way for the reintroduction of Western popular culture. The Reform period has seen the more sophisticated dominance of popular culture practices and products in Indonesia. In this paper, I also show how the enormous success of forms of popular culture has influenced political elites, particularly in the Reform period, in their attempts to win the masses.
\end{abstract}

Keyword: Popular culture, cultural policies, political elites

\section{Introduction}

In Indonesia, popular culture burgeoned dramatically after the end of the Old Order government in 1967. The Old Order government particularly in the period of Constitutional Democracy (1959-1965) imposed heavy restrictions upon Western popular culture. In that period, Sukarno, Indonesia's first president, preached about the evils of rock and roll music and waged war on the Beatle's music (Farram, 2007). Indonesian government, in the 1960s, forbade Hollywood movies for the reason that they were part of neocolonialism and imperialism and would sway people away from revolution (Budiman 2002:140,186). The retention and development of Indonesian culture both on the local and national stages - were seen as very important to the development of the country. Consequently, Western-influenced popular culture was deemed a threat and impediment to the development of an Indonesian culture that the government wanted to build.

\section{Method}

In this paper, I did literature survey on how Indonesian political elites in three major historical periods treat popular culture. I selected references based on historical categories: Old Order, New Order, and Reform Order.

\section{National Culture and Popular Culture}

According to Kleden (1987:236-237), the Old Order, in the era of Guided Democracy, treated national culture as a tool to deny the influence of foreign culture, particularly that of Western popular culture, as well as to unite the country using a constructed national identity. President Sukarno urged Indonesian youth to oppose cultural imperialism and to eschew Western popular music, in particular rock and roll (Farram, 2007:249). President Sukarno's treatment of national culture in the Guided Democracy era implied what Kleden (1987:233) has called a 'nationalisation of culture'. National culture was used by the Old Order regime to unify local cultures in order to push 
out Western culture's influence and penetration (Farram, 2007:247) and enhance national pride. In the New Order, led by President Suharto, national culture was used to control political opponents and repress intellectual criticism; Western popular culture was much more welcome, though not without criticism from some members of society. The way Suharto employed the national culture jargon resulted in a dual policy. On the one hand, there was 'internationalisation of culture'. On the other hand, the New Order government repressed dissenting political and intellectual opinions. It refused to allow the development of ideas that it considered would threaten national stability, thus forcing some intellectuals in Indonesia, particularly among stateinfluenced academic circles, to hide their critical thinking.

The New Order's warm reception of Western-style popular culture was exemplified by numerous imported Hollywood movies (Sen, 1994:49). Ironically, while the New Order let in the flow of foreign capital and forms of popular culture, as well as Western ideas about economic liberalisation in the form of national development policy, they refused the other side of it, i.e. Western ideas about political liberalisation, as it considered that such ideas conflicted with Indonesian national culture. The New Order regime banned artists who dared to make any implied criticism of their regime in their works (Farram, 2007:271). However, there were some exceptions, as musical tapes and performances by Iwan Fals, a pop superstar, and his associates, and Rhoma Irama, a dangdut musician, were not banned during the end of the 1980 s and the beginning of the 1990s (Murray, 1991:10-12). Their lyrics contained social comment on issues such as urban poverty, exploitative businessmen, the restlessness of the youth, opposition to materialism, and increasing inequality in society.

\section{Popular Culture In Indonesia After The New Order}

Budiman (2002:141-144) points out that New Order policies implied not only a flow of foreign capital to all parts of Indonesia, but also resulted in almost all aspects of the lives of Indonesians being influenced by the cultural values of industrial societies in Europe and USA. In the New Order era, cultural influences from the West became much more powerful than they had been under the Old Order.

The blossoming of popular culture in the New Order is also due to the development of the mass media, and modern mass communication technologies. In its earlier period (1966 to early 1970s), the New Order government allowed more freedom of expression than in its later period (late 1970s to 1990s). This can be seen in the increasing number of mass media channels and publications, which in turn promoted Western popular culture, as well as Asian popular culture (Japan, India, Hong Kong, Taiwan and Korea) from the early 1970s. Teen magazines, popular novels and Japanese comic books were enjoyed by many youth in urban areas from the end of the 1960s (Kailani, 2010. Handajani (2005:87) mentioned that teen magazines which focus on current fashion, celebrity gossip, and music have been constructing codes of sociability which became cultural references for Indonesian youth, and thereby have taken an important role in constructing youth culture, which is a very significant part of popular culture (Budiman, 2002:172).

Apart from printed media, electronic media have also developed enormously. Kitley (2000:16) concludes that the government introduced private channels to extend their hegemony from merely the politico- 
ideological sphere (national development and national culture) to the consumption sphere (driven by the dynamics of public demand and transnational flows).

Following the end of the New Order era, the number of free-to-air TV stations has been increased to fourteen. Since TV managements have to rely on commercial advertisements, making them a very important element within the neoliberal market economy. Television shows did not only contain information and entertainment, they also introduced cultural patterns, morality, and ethics of other societies from all over the world to their viewers (Budiman, 2002:176). For example, Indonesians, since the era of private TV channels, have been introduced to Nobita, a character from Doraeomon (a Japanese cartoon series) who - despite being lazy and unintelligent - can have everything he wants. Hairstyles, fashion, fast-food, American family-style kitchens, Hollywood stars, Taiwanese boy bands, Korean TV shows, and so forth have become regular and much celebrated by Indonesian families in their everyday life. In the post-1998 era, the role of media as a popular culture agent has accelerated significantly.

Currently, the power of popular culture practitioners to influence the majority of people in Indonesia has encouraged important figures, including politicians, to try as much as they can to be relevant, attractive and up to date in the eyes of society (Heryanto, 2008:5). Indonesia's current president, Susilo Bambang Yudhoyono, and Wiranto, one of his opponents in the 2004 Presidential election, repeatedly sang to the public during the election campaign to try to woo the masses. Other candidates also vied for media coverage and public support by performing either as singers or as readers of poetry.
During his presidency, in order to make up for his shortcomings of policy and failure in the handling of some cases, and to try to maintain his popularity, Yudhoyono has made a few musical albums in which several top musicians sang his compositions. Since the 2004 election, several top names in the world of music, TV, cinema, and fashion have aired their popular charm to campaign for either their preferred political parties or for themselves as candidates for parliament at local and national levels. Some artists also ran for local government elections, either as the head of government or as deputy. Some were not successful; some were, to the extent that they defeated the more politically experienced incumbents (Heryanto, 2010:186). Apart from the elites, the significance of popular culture in the Reform period is also evidenced by the fact that no other social institutions have been able to attract the public's attention on the scale or with the intensity of the electronic media (Heryanto, 2008:5).

\section{Conclusion}

Popular culture producers have been always targeting the youth as their main consumers. In Indonesia, there are many consumer products that make young people as their market target. Forms of mass media, particularly films and advertisements, are also saturated with images of young people. Here, young people are regarded as fragile and vulnerable to the influence of popular culture, thus elites of politics take popular culture as an intermediary to approach young people, either to exploit or to protect them. It is in this interest, political elites devise policy to manage popular culture. 


\section{References}

(1) Budiman, Hikmat. (2002). Lubang Hitam Kebudayaan [The Black Hole of Culture]. Yogyakarta: Kanisius

(2) Farram, Steven. (2007). Wage War against Beatle Music! Censorship and Music in Soekarno's Indonesia. Review of Indonesia and Malaysian Affairs, 41 (2), 247-277

(3) Handajani, Suzie. (2005). Globalizing Local Girls: The Representation of Adolescent in Indonesian Female Teen Magazines. Unpublished Thesis for the Degree of Master of Arts at the University of Western Australia,

(4) Heryanto, Ariel. (2008). Pop Culture and Competing Identities. In Ariel Heryanto (ed.), Popular Culture in Indonesia: Fluid Identities in Post Authoritarian Politics (pp.1-33). Oxon: Routledge

(5) (2010). Pop Islam in Indonesia.

Asian Currents: The Asian Studies Association of Australia's e-bulletin, February. http://asaa.asn.au/publications/ac/asian-currents10-02.html\#5b, accessed 15 March 2010

(6) Kailani, Najib. (2010). Muslimising Indonesian Youths: The Tarbiyah Moral and Cultural Movement in Contemporary Indonesia. In Ahmad-Norma Pemata and Najib Kailani, Islam and the 2009 Indonesian Elections, Political and Cultural Issues: The Case of the Prosperous Justice Party (PKS). Bangkok: IRASEC

(7) Kitley, Philip. (2000). Television, Nation and Culture in Indonesia. Athens: the Ohio University Center for International Studies

(8) Kleden, Ignas. (1987). Sikap Ilmiah dan Kritik Kebudayaan [Scholarly Outlook and Cultural Criticism]. Jakarta: LP3ES
(9) Murray, Alison. (1991). Kampung Culture and Radical Chic in Jakarta. Review of Indonesian and Malaysian Affairs. 25 (1), Winter, 1-16

(10) Sen, Krishna. (1994). Indonesian Cinema: Framing the New Order. London: Zed Books 